\title{
IMPACT OF CLIMATE CHANGE ON WATER RESOURCES: A CASE STUDY OF TAUNI DEVI BLOCK OF HAMIRPUR DISTRICT
}

\author{
Binita Kumari*1 \& Pawan K. Attri ${ }^{2}$ \\ ${ }^{* 1,}{ }^{2}$ Institute of Integrated Himalayan Studies (UGC-Centre of Excellence) H.P. University Summerhill, Shimla -5 (H.P.) \\ *Corresponding Author: -
}

\begin{abstract}
: -
A study to know the status of climate change impact on water sources was conducted in villages of Tauni Devi Block of Hamirpur district of Himachal Pradesh. The study has shown that there are number of traditional drinking water sources in this area. The main traditional sources for the drinking water in study area are wells, baories and khatries. Piped water supply had also been provided to almost every house. A survey for drinking water status was conducted during the field survey and it is enumerated that the Total of 1302 (Khandera,550; Narsin,752) habitations are in the studied village. The piped water supply schemes are given from three different IPH division these are:Hamirpur, Bhoranj and Uhal. Water requirement and water supplied by IPH department to the above villages are Khandera;

38500 Ltrs, Narsin; 52640 Ltrs accordingly in 112+152 private tapes and 11 public tapes However IPH department take care of other source of water i.e., 9 hand pumps in two village.

Source of this water supply to the Khandera village is River Beas (underground water) LWSS Logwalti Bamson and to Narsin from Infiltration gallery at Gudhwin Khad. Climate change is likely to increase the variability of water resources affecting human health and livelihoods. The projected increase in the frequency and magnitude of high intensity rainfall events could affect infiltration and groundwater recharge with further implications for water availability for people as well as water accessibility for plants. The anticipated increase in variability in availability of water because of climate change should be dealt with by increasing water storage in its various forms, namely, soil moisture, ponds, ground water, small and large reservoirs and traditional water systems must be reexamined, reinvestigated and preserved.
\end{abstract}

Keywords: Climate change, Water resources, Hamirpur, Tauni Devi

\section{(c) $(\$)$}




\section{INTRODUCTION}

United Nation Framework Convention on Climate Change (UNFCCC) has defined climate change as a change of climate that is attributed directly or indirectly to human activity that alters the composition of the global atmosphere and that is in addition to natural climate variability observed over comparable time periods. Water is fundamentally an important resource because it is essential for survival; because its use underlies all agriculture and industrial processes; and because it cannot be technologically substituted for Industrialization and the accompanying urbanization have not only polluted the watercourses, but also created a growing demand for large quantities of protected water for public and for the industries. The impacts of climate change on freshwater resources affect the global population. At present, over one billion people already live in water-scarce areas. 22 By

2025, almost two-thirds of the world's population is projected to experience some kind of water-related stress and, for one billion of them, the shortage will be severe and socially disruptive.

Climate change can severely threat India's water security. India's hydro-climatic regime is expected to alter significantly over the course of the 21 st century. Himalayan glacial recession can prove havoc for the perennial Indus-Ganga surface water resources. The impacts of climate change on glacial recession, decreasing rainfall pattern in some parts of India, greater but variable rainfall pattern in other parts of the country can lead to drought and flood like situations. Increased evapo-transpiration and reduced soil moisture may increase land degradation and desertification. Above mentioned arguments coupled to the scenario that the water utilization rate in India is 59\%, much ahead of the $40 \%$ standard, clearly point to an urgent need to better adopt water management practices in the country to increase the water security for proper transition into a green economy. India has more than $18 \%$ of the world's population, but has only $4 \%$ of world's renewable water resources and $2.4 \%$ of world's land area. There are further limits on utilizable quantities of water owing to uneven distribution over time and space.

Himachal state had a very traditional, social and cultural heritage of conservation and judicious use of water that helped the mankind to survive over the centuries against all odds of the environment. Various water harvesting structures and techniques like Baorie, dug well, khatries, pond, choes, springs etc were practiced to suit particular site conditions. A unique system of Khatries was followed in some parts of the state for judicious use of rain water harvesting. Despite the fact that there was no intervention of the then rulers in the state, people managed the water resources optimally to survive, often drought like conditions. Water management is deeply rooted in the social fabric of the State, it is strange that very few public sources of drinking water were developed by the rulers. Mostly the sources were created by the public themselves. The local people have created numerous water bodies near to the villages. Baori and Baoli is one of the drinking source developed by the people. Wells are another important water body. There are different types of wells practiced in Himachal Pradesh. The wells may be owned by an individual or by a community. Khatri is an underground structure, where rain water can be stored. The stored water can last for few months without any deterioration of quality. In the context of climate change and water resources, this highlight (i) the water resources of Himarpur district with special reference to Tauni Devi Block, and the possible impacts of climate change on its water resources.

\section{Study Area \& Methodology}

The present study is based on data collected from Khandera and Narsin of Tauni Devi Block of Hamirpur. A preliminary field visit was made to get an idea of the indigenous water sources in the study area. Hamirpur is located in the southwestern part of the Himachal Pradesh and is situated between $76^{\circ} 17^{\prime} 50^{\prime \prime}$ ' $-76^{\circ} 43$ ' $42^{\prime}$ " east longitude and 31 $244^{\prime} 48^{\prime}$ '$31^{\circ} 53$ '35' north latitude. It is the smallest district of the Himachal Pradesh having a total area of 1118 square kms (2.01 $\%$ of the State). The district is bounded in the north by river Beas which separates it from the district Kangra. Most of the district lies within the range of 600 to $900 \mathrm{Mts}$ above MSL. The average annual rainfall of the district is $1200-1462 \mathrm{~mm}$. The different aspects of methodology followed regarding the selection of the study area, sampling design, selection of villages for detailed survey of indigenous water sources, collection of data and the techniques employed to meet out the objectives of the study. Each indigenous water sources in these villages were enumerated with the help of enumerators, Rural Development Department and panchayats.

\section{Result \& observation}

Hamirpur District was made in 1972 by carving it out from the Kangra district. The 1118 square kilometers geographical area supports population of 454,768 of which male and female were 217,070 and 237,698 respectively. In 2001 census, Hamirpur had a population of 412,700 of which males were 196,593 and remaining 216,107 were females.

Average literacy rate of Hamirpur in 2011 were 88.15 compared to 82.46 of 2001. If things are looked out at gender wise, male and female literacy were 94.36 and 82.62 respectively. For 2001 census, same figures stood at 90.15 and 75.70 in Hamirpur District. Total literate in Hamirpur District were 358,091 of which male and female were 180,555 and 177,536 respectively. In 2001, Hamirpur District had 298,498 in its district. Tauni Devi is situated between $76^{\circ} 18^{\prime}$ to $76^{\circ} 44^{\prime}$ East longitudes and $31^{\circ} 25^{\prime}$ to $31^{\circ} 52^{\prime}$ North latitude. It is situated at lower elevation and comparatively warmer but has some hilly ranges covered with Pine forests. Rain occurs mainly in middle of September, caused by the south west monsoons. Some rain is also received in the post monsoon month of October. A major portion of precipitation (74\%) is received during monsoon period from June to September. July and August are the wettest months. Cold in winter \& Hot in summer Rainy from July to Sept. Khandra and Narsin are the villages in Tauni Devi Tehsil of Hamirpur District of Himachal Pradesh State, India. It is located 12 KM towards North from District headquarters Hamirpur. 


\section{Demographics features of studied villages (2011)}

The two villages undertaken for the study i.e. Narsin and Khandera fall under panchayats namely Narsin .In Khandera the total population is 591( 287 males \& 304 females) i.e. $48.56 \%$ males \& $51.43 \%$ females. In Narsin the total population is 393 individuals (183 males \& 210 females) i. e., $46.56 \%$ male and 53.43\% females. It was found that Khandera had highest population followed by Narsin. It was also found that the male and females were almost equal in number (Table: 2 ). The average size of the family is four or less than five in both village, this is mainly due to either disintegration of joint family coupled with movement of people out of the area in search of better livelihood opportunities and more comfortable life. The climate in various parts of the district depends much on the elevation which varies from less than $200 \mathrm{~m}$ to more than $1000 \mathrm{~m}$ above mean sea level. The climate of the district can be divided into three seasons namely: summer (March to $3^{\text {rd }}$ week of June), Monsoon or rainy (last week of June to end of September), and winter (October to February).

\section{WATER SOURCES}

Water is one of the most vital natural resources of Himachal Predesh. The state is richly endowed with a hilly terrain having an enormous volume of water from the catchment areas of Satluj, Beas, Ravi and Chenab rivers. As such, the state has enormous potential of water resources in the form of glaciers and rivers but ground water resources are limited. The major consumptive use of water in the State has been for irrigation. The gross irrigation potential of the State is estimated to be 3.35 lakh hectare, while the irrigation potential created has reached 2.56 lakh hectare by September 2013. Most of the surface water resources of the state flow from perennial rivers which originate from glaciers. The flow in these rivers is further augmented by run-off from the catchment area. The groundwater resources occur mainly in unconsolidated sediments of intermontain valleys and in the submontane tract. Kangra, Una, Hamirpur, Bilaspur, Mandi, Solan and Sirmaur districts, particularly their valley areas depend upon groundwater. The exploitation is done through open wells, tubewells, infiltration galleries and wells. As there is an imbalance between the supply and consumption of water, particularly by the poor and weaker sections of the society, the traditional sources of water play a significant role. These include springs, Khuls, Baories, Ponds, Khaties and ditches particularly in Himachal Pradesh. Water sources to the studied villages mainly are hand pumps, public taps, private taps, wells, Nrega Khatries and Own khatries.

\section{Types of Drinking Water Sources}

The following are the major types of traditional drinking water sources in the state.

\section{Baori or Baoli:}

Baori is constructed mainly from stones around a natural water spring. It is an age-old traditional drinking water source in lower areas of Himachal Pradesh. A big size Baori is called Noun. Water is collected in a small shallow receptacle. Baori is generally covered with a roof but sometimes may be without roof. The outlet from Baori is through a narrow hole fixed with a pipe or nallah outside. Some baoris are open at the front. The entire village normally constructs it and community participation and utilization of this water are main features. It is an unique method of water extraction and storage in the villages. Generally, temples of lord Shiva have been constructed near these baories.

Nallas: 'Nallas' are generally placed by individuals in memory of their kin. These 'nallas' are usually made of wood and fixed directly at the outlet of ground water either by constructing a platform or at a high ground.

Chos': 'Chos' are for collecting rainwater. It is rocky hard platform dug deeply to store water, which can be used later on.

Springs: Free flowing water from spring is also a potential traditional source of water in the villages.

\section{Dug wells}

An open well is a well of relatively large diameter, varying from 2 to $10 \mathrm{~m}$. It is dug into ground to tap water only from the top pervious strata. The depth of an open well is usually limited to $30 \mathrm{~m}$. The greater depth is not economically feasible. The open well may be lined or unlined. In a lined well, the entry of water into the well is from the bottom and not from the sides. The open well generally penetrates 5 to $8 \mathrm{~m}$ below the water table, so that minimum infiltration head (or drawdown) of 3 to $5 \mathrm{~m}$ is available even in a dry year. The discharge from open well is generally limited to 5 liter per seconds.

\section{Khatries}

In this area almost every house has a khatrie to store rainwater. Each Khatri is a cave like structure constructed by cutting the conglomerate rock. The khatries constructed by the individuals are well protected in almost all the cases and have been provided with a door and lock arrangement. The Khatries constructed by the individuals are well protected in almost all cases and have been generally provided with a door.These Khatries are generally constructed under the ground floor of a house or the in the courtyard of the house. Sometimes these are also constructed away from the houses and are protected with door and locking arrangement. These are constructed in the conglomerate rocks. The average size of the Khatrie is $3.6 \mathrm{~m}$ X $3.0 \mathrm{~m}$ X $2.5 \mathrm{~m}$. The depth of Khatries varies from $2.0 \mathrm{~m}$ to $3.0 \mathrm{~m}$. Each house has one or two Khatries to store rainwater. The water is used for washing clothes, utensils and to cater the cattle demand. There are two types of 
khatries, one for animals and washing purposes, in which rain water is collected through gutter and down pipes and the other type is used for human consumption in which rain water is collected by seepage through rocks. Interestingly, the khatries are owned by individuals as well as by a community, the former being more common. There are Government Khatries as well which are maintained by the Gram Panchayat.

\section{Piped water sources}

Not only human race, but the entire creature on the earth needs water to drink, air to breathe and food to eat. Among the basic needs, "Water" is thought even more important than food. During ancient days the people of Himachal Pradesh used to fetch water from boudies, ponds, rivers, khatries, springs, tanks and khads in the vicinity of the habitations. At the time of independence, pipe drinking water facilities in the State were almost negligible. To provide safe drinking water to the people of state was felt by State Government as well as by Central Government. Accordingly, efforts were made to provide potable drinking water at their doors through piped water supply system.

Upto early seventies, drinking water supply in the state mostly used to be provided through alkathene pipes. Later on, the system was replaced with G.I. pipes. To provide drinking water facilities in all villages / sub-villages, Govt. of India had launched Accelerated Rural Water Supply Programme during the year 1971. A survey for drinking water status was conducted during the field survey and it is enumerated that Total of 1302 (Khandera,550; Narsin ,752) habitations are in the studied village. The piped water supply schemes are given from three different IPH division these are:Hamirpur, Bhoranj and Uhal. Water requirement and water supplied by IPH department to the above villages are Khandera; 38500 Ltrs, Narsin; 52640Ltrs accordingly in $112+152$ private tapes and 11 public tapes However IPH department take care of other source of water i.e., 9 hand pumps in

two village. Source of this water supply to the Khandera village is River Beas (underground water) LWSS Logwalti Bamson and to Narsin from Infiltration gallery at Gudhwin Khad.

\section{Climate Change \& Water Resources}

A scarce natural resource, water is fundamental to life, livelihood, food security and sustainable development. India has more than $18 \%$ of the world's population, but has only $4 \%$ of world's renewable water resources and $2.4 \%$ of world's land area. There are further limits on utilizable quantities of water owing to uneven distribution over time and space. In Himachal Pradesh availability of water is highly uneven in both space and time. Precipitation is confined to only about three or four months in a year and varies from about $600 \mathrm{~mm}$ in Lahaul \& Spiti district to around $3200 \mathrm{~mm}$ in Dharamshala District Kangra. However, in spite of heavy rain and snow during the rainy season and winter the summer months are periods of water scarcity in many areas as the flow in the rivers and nallahs is quite low and traditional sources also dry up. This results in forced migration of humans and animals to the banks of rivers with perennial flows. On the other hand, heavy rains regularly cause havoc due to floods. Flash floods also cause damage in the higher reaches of the State. In addition, there are challenges of frequent floods and droughts in one or the other part of the state. With a growing population and rising needs of fast developing urbanization \& higher living standards, as well as the given indications of the impact of climate change, availability of utilizable water will be under further strain in future with the possibility of deepening water conflicts among different user groups. Low consciousness about the scarcity of water and its life sustaining and economic value results in its mismanagement, wastage, and inefficient use, as also pollution and reduction of flows below minimum ecological needs. In addition, there are inequities in distribution and lack of a unified perspective in planning, management and use of water resources.

\section{Impact of climate change on water resources}

Climate change will have a range of direct and indirect impacts on both the environment and the people of the Himalayan region. These impacts are closely interlinked, ranging from biodiversity impacts and related effects on ecosystem goods and services, through impacts on water balance and availability and hazards, to socioeconomic and health impacts on the population. The impacts are embedded in and affected by a range of other global and local drivers of change.

The impacts of climate change are not only important in the context of ecosystem services, but also in connection with the overall water regime and with hazards. Despite the importance of water and the fact that climate change may have a profound impact on it, there have been few quantitative analyses of changes to water regimes in the Himalayas due to the dearth of the baseline data which is essential for such analyses. Even so, it is clear that the hydrological systems of the Himalayas are very sensitive to climate change, variability, and extremes, both on a seasonal basis and over longer time periods. The shifts in precipitation and temperature can have a considerable impact on future flow regimes. Global warming is accelerating the melting of glaciers in the Himalayas, which are melting faster than the global average (ICIMOD and UNEP 2000; Dyurgerov and Meier 2005; Bajracharya et al. 2007); the snow line will rise and potentially some glaciers could disappear or stabilize at a much-reduced mass (IPCC 2007a; 2007b). In the short term, this means an increase in melt water; in the longer term, a reduction. Spatial analysis of water balance components indicates that stream flows will increase significantly across most of the Himalayas in response to precipitation and temperature changes, but effects will vary spatially. Overall increases are likely to be more in the wet months, with a potential reduction in the dry months - which could have serious impacts on the populations relying on rivers fed by melt water from the Himalayas. The projected increase in the frequency and magnitude of high intensity rainfall events could affect infiltration and groundwater recharge with further implications for water availability for people as well as water accessibility for plants. Much concern has also been expressed about the likely impact of the increased variability in flow on hydropower generation in the region (Alam and Regmi 2004). 
Changes in Surface Water Resources: There have been many studies globally to assess trends in river flows. However, no homogeneous pattern has been observed. Difficulties were found in assessing trends and differentiating these from increases in abstraction over time and changes in the catchment conditions. At a global scale, there is more coherent evidence of changes in annual runoff with some regions experiencing an increase and others, a decrease. For Himachal Pradesh, the very high levels of hydroelectric and other infrastructure development in rivers and lack of long-term records make estimates of trends difficult.

Glacier and Snow Changes: The glaciers can provide a very useful measure of temperature trends-especially relevant in Himachal Pradesh. There are differing assessments of the rates of retreat and longevity of the glaciers. Less well defined is the percentage of dry season river flows that is attributable to the glaciers. Nineteen glaciers in the Baspa basin were monitored over a period 1962 to 2001 . The investigation showed that all the glaciers were receding and overall, 19 per cent deglaciation was observed in the period. Glaciers at around $5000 \mathrm{~m}$ elevation showed 24 per cent loss compared with 14 per cent loss for glaciers above $5400 \mathrm{~m}$. The mean glacier terminus has moved vertically about $88 \mathrm{~m}$. Change in the snowfields is less conclusive and is influenced by the annual cyclical variations of rainfall. An extensive analysis of rainfall and temperature patterns at different elevations is required. Assessments of glacier change are complex and should be based on a study of the mass balance and the location of the equilibrium line. The linkages between trends in climate and trends in glacier extent (length, area, volume, and melt volumes) are of key concern to the future water resources of Himachal Pradesh as well as of downstream states. The consensus is that glaciers around the world are shrinking primarily because of global warming; the precise rate of melt is still not well re searched.

Average Rainfall: The consensus is that globally, rainfall has and will increase primarily due to increased evaporation due to higher temperatures. There are however, many anomalies. For example, over much of northwest India, the period 1901 to 1925 shows increase of more than 20 per cent over the 100-year period, but the same area has shown significant decreases since 1979. This trend is now apparent in some parts of Himachal Pradesh.

Extreme Rainfall Events: Globally, it is considered very likely that heavy precipitation events will become more frequent. The intensity of precipitation events is projected to increase especially in areas which experience increases in mean precipitation. In most tropical and mid-latitude areas, it is estimated that extreme precipitation will increase more than mean precipitation. Widespread increases however, in heavy precipitation events (e.g., above the 95th percentile), have been observed even in places where total amounts have decreased. These increases are associated with increased atmospheric water vapour and are consistent with observed warming.

Temperature: The best-estimate linear trend in global surface temperature from 1906 to 2005 is a warming of $0.74{ }^{\circ} \mathrm{C}$ (likely range 0.56 to $0.92^{\circ} \mathrm{C}$ ), with a more rapid warming trend over the past 50 years. Future projections depend very much on international actions to reduce emissions, presently targeted at less than $1.5^{\circ}$ to $2.0^{\circ} \mathrm{C}$.

Potential Evaporation: This is projected to increase globally due to increase in the waterholding capacity of the atmosphere from higher temperatures and non-marked change in relative humidity. Water vapour deficit in the atmosphere increases as a result, as does the evaporation rate. Actual evaporation over open water is projected to increase with spatial variations in surface warming. Changes in evapotranspiration over land are controlled by changes in precipitation and radiative forcing, which would in turn, impact on the water balance of runoff, soil moisture, water in reservoirs, and the ground-water table.

Droughts: There are linkages between intense precipitation and droughts. The projected increase in the risk of in tense precipitation and flooding is associated with the risk of drought. Increased precipitation is projected to be concentrated in more intense events resulting in longer periods of lower precipitation in between. Intense and heavy episodic rainfall events with high runoff amounts are likely to be in trespassed with longer relatively dry periods with increased evapotranspiration, particularly in the sub-tropics. Depending however, on the threshold used to define such events, an increase in the frequency of dry days does not necessarily mean a decrease in the frequency of extreme high-rainfall events. Another aspect of these changes is related to changes in mean precipitation; the projection is that in general, wet extremes will become more severe in areas where mean precipitation increases, and dry extremes, more severe where mean precipitation decreases. Multi-model climate projections for the 21 st century show increases in both, precipitation intensity and number of consecutive dry days in many regions. Precipitation intensity will increase almost every where, particularly at mid and high latitudes where mean precipitation also increases.

\section{Effects of Climate Change Seen in Himachal Pradesh}

The scope of the study does not allow a full and comprehensive analysis of the water sector parameters under climate variability in Himachal. Some indicators include People's Perception. It is evident that farmers are now observing the impact of climate change. Rural knowledge of the changes is in many ways, quite advanced through the day to day seeing and feeling of the changes. Observed parameters include:

- Movement to higher altitudes of apple orchards

- Loss of various tree species

- Drying of traditional water sources

- Changing of bird types and populations 
- Reduction of crop yields

- Increased vulnerability of crops due to drought and delays in planting.

\section{Adaptation to Climate Change}

Climate change is likely to increase the variability of water resources affecting human health and livelihoods. Therefore, special impetus should be given towards mitigation at micro level by enhancing the capabilities of community to adopt climate resilient technological options. The anticipated increase in variability in availability of water because of climate change should be dealt with by increasing water storage in its various forms, namely, soil moisture, ponds, ground water, small and large reservoirs and their combination. States should be incentivized to increase water storage capacity, which inter-alia should include revival of traditional water harvesting structures and water bodies. The adaptation strategies could also include better demand management, particularly, through adoption of compatible agricultural strategies and cropping patterns and improved water application methods, such as land leveling and/or drip / sprinkler irrigation as they enhance the water use efficiency, as also, the capability for dealing with increased variability because of climate change. Similarly, industrial processes should be made more water efficient. Stakeholder participation in landsoil-water management with scientific inputs from local research and academic institutions for evolving different agricultural strategies, reducing soil erosion and improving soil fertility should be promoted. The specific problems of hilly areas like sudden run off, weak water holding capacity of soil, erosion and sediment transport and recharging of hill slope aquifers should be adequately addressed. Planning and management of water resources structures, such as, dams, flood embankments, tidal embankments, etc., should incorporate coping strategies for possible climate changes. The acceptability criteria in regard to new water resources projects need to be re-worked in view of the likely climate changes.

\section{Conclusions and Recommendations}

A study to know the status of climate change impact on water sources was conducted in villages of Tauni Devi Block of Hamirpur district of Himachal Pradesh during this study. The study has shown that there are number of drinking water sources in this area. The main sources for the drinking water in study area are wells, baories and khatries. Though the piped water supply had been provided to almost every habitation, the level of service delivery is far from satisfactory besides mounting operation and maintenance cost. There is heavy misuse of water by the public residing near the storage tanks and the tail-enders are the major sufferers. They hardly get a few buckets of water during summer months and at that time they have no option but to bring water from traditional drinking water sources. Since most of the drinking water sources have been polluted, people using this water suffer from water borne diseases. People have no option but are forced to bring water from traditional sources, when there is no supply from piped water supply scheme due to power failure, breakdown of machinery or disruption in pipelines. Baories, dug wells, step wells, khatries and springs are the traditional water harvesting structures that have been used as source of drinking water in this region over the centuries. Some time in many villages these systems have fallen into disuse with the spread of piped water supply. Traditional water harvesting systems definitely have more relevance in areas where water scarcity in acute or where ground water is too deep to obtain cheaply. However, in some areas a supplementary source may be necessary. Traditionally, in these areas people have developed cultural practices which encourage judicious use of water but now these practices are dying. Water conservation education needs to be encouraged.

A revival of drinking water sources is essential Revival of traditional systems will have to take into account the State's ecological diversity. Imposing some technology in the varied regions of the State will be unsuccessful. The relevance of each technology in its local context must be addressed. The issues involved in the revival of the traditional systems are intricate and interlinked planning for their revival must be ecosystem-specific and location specific. The control of these systems must lie with the people and the system must be based on the needs and capacities of the people so as to ensure their sustainability.

There is indeed a strong case for a major effort at renewing and improving the local systems. For instance, modern techniques like, sand filled reservoirs, ground water recharge structures, check dams and ground water dams are possible alternatives. Effort should be made to develop ground water recharge structures in drought prone areas of the State. Attempt to restore traditional systems must be based on a clear understanding of whether the conditions for their restoration are today present or not and whether it is or it is not possible to adopt to these. The knowledge base of the user communities must be utilized as they have firsthand knowledge and experience which no expert can match, for example construction of khatries in some parts of the State.

\section{Suggestions}

For sustainable development of water sources, the following measures are suggested

- To meet the water demand of increasing population, urbanization and industrialization the traditional water systems must be re-examined, reinvestigated and preserved.

- Periodic monitoring of water quality must be ensured to check the deterioration in their quality

- People participation and environmental education are pivotal and needs to be encouraged.

Since not much research has been done on Climate change and its impact on water sources of the Himalayas, the study is a beginning in this direction and not an end. Much more research is yet required to be done. Multidisciplinary research on water sources of the entire state is required. Deeper and wider applications of the social, economic and managerial aspects the system is necessary. The water quality of all the water sources must be monitored regularly and database needs 
to be developed. Water is major force in socio-economic growth of the region. If the development of water sources has to be sustainable, equitable and community-based systems have to be rejuvenated, developed and preserved.

\section{References}

[1].Anita kumari, P Kaushal, Jk Dubey and Dk Sharma (2012) Climate change - an impact study in Himachal Pradesh International Journal of Farm Sciences 2(2) 95-101.

[2].C. P. Kumar (2012) Climate Change and Its Impact on Groundwater Resources International Journal of Engineering and Science Vol. 1, Issue 5 PP 43-60.

[3].D. Viviroli, et al., (2011) Climate change and mountain water resources: overview and recommendations for research, management and policy Hydrol. Earth Syst. Sci., 15, 471-504.

[4].Dileep Kumar (2009) Impacts of Climate Change in India Paper presented in $2^{\text {nd }}-$ India

[5].Disaster Management Congress (4-6) November 2009, Vigyan Bhavan, New Delhi.

[6].Eddy J. et. al. (2011) Adaptation to changing water resources in the Ganges basin, northern India environmental science \& policy $14,758-769$.

[7].G. C. S. Negi, P. K. Samal, J. C. Kuniyal, B. P. Kothyari, R. K. Sharma \& P. P. Dhyani (2012) Impact of climate change on the western Himalayan Mountain ecosystems: An overview Tropical Ecology 53(3): 345-356.

[8].Gosain A.K. (2011) Impact of Climate Changes On Water Resources CURRENT SCIENCE, VOL. 101, NO. 3 , 10.

[9].H. Middelkoop, et. al., (2001) Impact of climate change on hydrological regimes and water resources management in the rhine basin Climatic Change 49: 105-128.

[10]. Hari Pal Singh, M.R. Sharma, Quamural Hassan, Naved Ahsan (2010) Impact of drought on drinking water resources of Himachal Pradesh Biological Forum — An International Journal, 2(1): 73-77.

[11]. Hari Pal Singh, Prof. M.R. Sharma and Prof. Quamrul Hassan (2014) Developing a Framework for Sustainable Drinking Water Supply and Irrigation Projects in Shivalik Area of Himachal Pradesh International Journal on Emerging Technologies 5(1): 46-53.

[12]. Harjeet Singh, (2009) Climate Change Adaptation: Is It All About 'Good' Development? Paper presented in $2^{\text {nd }}-$ India Disaster Management Congress (4-6) November 2009, Vigyan Bhavan, New Delhi.

[13]. Kumar Manoj and Padhy Pratap Kumar Climate Change, Water Resources and Food Production: Some Highlights from India's Standpoint (2013) International Research Journal of Environment Sciences Vol. 2(1), 79-87.

[14]. M. Akhtar A, N. Ahmad A, M.J. Booij (2008) The impact of climate change on the water resource sof HindukushKarakorum-Himalaya region under different glacier coverage scenarios Journal of Hydrology 355, $148-163$.

[15]. Martin Beniston A, Markus Stoffel (2013) Assessing the impacts of climatic change on mountain water resources Science of the Total Environment xxx (2013) xxx-xxx.

[16]. R. D. Singh, Manohar Arora, and Rakesh Kumar Climate Change, Its Impact On Water Resources And Adaptation Strategies (2009) paper presented in $2^{\text {nd }}-$ India Disaster Management Congress (4-6) November 2009, Vigyan Bhavan, New Delhi.

[17]. R.Jindal and D.Singh (2013) Water Analysis of Kunah Stream in Relation to Biodiversity Distt. Hamirpur, (HP) Society of Applied Sciences Vol 4 (3).

[18]. R.S. Chandel and M.R. Sharma (2013) Potential and Limits of Domestic Rooftop Water Harvesting in Hamirpur Area of Shiwalik Hills International Journal of Theoretical and Applied Science 5(1): 97-102.

[19]. Ranjan, P., Kazamaa, S. and Sawamoto, M. (2006), Effects of climate change on coastal fresh groundwater resources, Global Environmental Change, Vol. 16, pp. 388-399.

[20]. Ratan Chand Sharma, Anil K. Gautam and Shivani Dogra (2012) Physicochemical Characterization of the Water of Lower Himalayas of Himachal Pradesh Vol. 2. No.1\&2. 24-47.

[21]. Sanjay Kumar (2013) Morpho-Metric Analysis of Kunah Khad, Himachal Pradesh Journal Of Humanities And Social Science Volume 6, Issue 3, PP 01-09.

[22]. Tim Barnett, Robert Malone, William Pennell, Detlet Stammer, Bert Semtner and Warren Washington (2004) The effects of climate change on water resources in the west: introduction and overview Climatic Change 62: 1-11.

[23]. Vinay K. Pandey, Ajai Mishra, Shashank S Mishra (2015) Climate Change and Mitigation Measures for The Hydrometerological Disaster In Himachal Pradesh, India- In Light Of Dams International Journal Of Scientific \& Technology Research Volume 4, Issue 01.

[24]. Vinson Kurian Climate Change: To Learn to Adapt Is the Best Policy (2009) paper presented in $2^{\text {nd }}-$ India Disaster Management Congress (4-6) November 2009, Vigyan Bhavan, New Delhi.

[25]. Zhou, Yu, Zwahlen, François, Wang, Yanxin and Li, Yilian (2010), Impact of climate change on irrigation requirements in terms of groundwater resources, Hydrogeology Journal, Vol. 18, pp. 1571-1582. 